\title{
PŘEKLAD JAKO ROZHODOVACÍ PROCES: ROZPRACOVÁNÍ KONCEPTU J. LEVÉHO A APLIKACE TOHOTO PŘÍSTUPU NA INSTITUCIONÁLNÍ PŘEKLAD
}

\author{
TOMÁŠ SVOBODA
}

\begin{abstract}
Translation as a decision process - Jiří Levý's concept developed further and applied to institutional translation

This paper links three areas: reflections on translation as a decision process, the field of institutional translation, and translation manuals / style guides.

Inherently, human translation is a decision-making process. As such, the process is subject to standards, specifications, and other restricting features. This is true for both literary and non-literary translation. The present article looks at institutional translation through a decision processprism, paying special attention to translation manuals and style guides. The paper is divided into two main parts: In the first part, Jiří Levýs concept of translation as a decision-making process is formalized to establish a model. The model eventually includes a taxonomy of ten distinctions: (1) Selecting the text to be translated; (2) Primary level vs. meta level; (3) Subsumption of (definitional and selective) instructions; (4) Acceptance vs. non-acceptance of instructions; (5) Quantitative vs. qualitative aspect of decision-making; (6) The quantity of decisions made by a translator compared to those taken by the original author; (7) Necessary vs. unnecessary surplus decisions; (8) Motivated vs. unmotivated decisions; (9) Selective instructions; (10) Conscious vs. unconscious decisions. The model is then represented in a concise flow chart.

The paper also compares relevant passages of the earlier English version of Translation as Decision Process (1967) and the original Czech version from 1971. The comparison shows a shift in Levýs understanding of translation process over time.

In the second part, the above-mentioned taxonomy is applied to non-literary translation, specifically to the highly regulated context of institutional translations. Since institutional translation is predominantly governed by (written and unwritten) rules that affect translators' decisions, it is translation manuals and style guides that play a key role in a translator's decision process. Linking the newly devised model of the decision process with such manuals and/or style guides has proven to be a suitable way of creating a taxonomy for the latter, which has always been missing from research into such resources. The model bridges differences between various types of institutional discourse (here, supranational, corporate, and non-profit organisations are scrutinized). The current paper proposes a general systemization grid for translation manuals and style guides, by allocating individual resources to individual distinctions (No. 1-10) of the
\end{abstract}


model. In addition, the contribution also points to the potential of game theory in exploring institutional translation.

Keywords: translation; decision proces; Jiř́ Levý; institutional translation; translation manuals and style guides; game theory and translation

\section{1. Úvodní poznámka}

V tomto př́spěvku propojujeme tři témata: překlad jako rozhodovací proces, institucionální překlad a problematiku překladových příruček a stylistických pokynů. V první stěžejní části př́spěvku (oddíl 3) pojednáme o rozhodovacím procesu v pojetí Jiř́ho Levého, přičemž toto pojetí rozpracujeme do podoby formalizovaného modelu. Takto vzniklý model je pak ve druhé stěžejní části tohoto prríspěvku (oddíl 4) aplikován na oblast tzv. institucionálního překladu, a obzvláště pak na překladové př́ručky a stylistické pokyny, jejichž př́tomnost je považována za jeden z charakteristických rysů překladatelské činnosti $\mathrm{v}$ institučním prostř̌edí. Výběrově se zabýváme př́ručkami používanými u tří typů institucí, a to u nadnárodních institucí, neziskových organizací a institucí komerčního charakteru.

Jestliže platí, že překlad je rozhodovací proces, pak k prohloubení poznání v oblasti překladu obecně, a odborného (či neliterárního) překladu zvláště, je podstatný výzkum toho, čím je takový rozhodovací proces ovlivňován.

Začněme připomínkou známého stanoviska J. Levého:

Překládání $\mathrm{z}$ hlediska pracovní situace překladatele $\mathrm{v}$ každém okamžiku jeho práce [...] je rozhodovací proces, tj. série určitého počtu posloupných situací - tahů jako ve hře -, v nichž se překladatel vždy musí rozhodovat mezi určitým (a zpravidla dosti přesně definovatelným) počtem alternativ. (1971: 73, zvýraznění původní)

Níže si ukážeme, čím je podle Levého takový rozhodovací proces (slovy J. Levého „akt volby“ nebo též „taktika výběru“) určován a jak tato problematika souvisí s institucionálním překladem, konkrétně pak s překladovými ${ }^{1}$ př́ručkami a stylistickými pokyny. Budeme vycházet především $\mathrm{z}$ textu Levý 1971 a přihlédneme též k původnímu pojednání Levý 1967.

Předmětem různých př́spěvků $\mathrm{k}$ problematice překladu (at už literárního, či neliterárního) bývají často pojednání o konkrétních přeložených textech. Takové texty bývají analyzovány $\mathrm{z}$ různých (často převážně lingvistických) hledisek, přičemž se však na základě analýzy konstatuje, jaké jevy byly doloženy či zjištěny, ale ne vždy se v takových pojednáních objevuje rozměr explanační.

Uvedený postř̌eh se týká i dílčích oblastí translatologie, výzkumu právního překladu (Legal Translation Studies, LTS) či institucionálního překladu: Až př́liš̌ často se v různých analýzách či pojednáních odhliží od příčin zjištěných jevů. Je zřejmé, že v komunikačních situacích tak složitých, jako je právě nap̌r. institucionální překlad, se na výsled-

1 V textu se zde rozlišuje mezi adjektivem překladový (týkající se překladu, zde zejména jako procesu) a překladatelský (týkající se překladatele). 
ném produktu překladového procesu podílí celá řada osob a úrovní rozhodování. Většina „aktů volby“ však, domníváme se, probíhá v rámci překladatelského procesu v užším slova smyslu, tedy při tzv. interaktivním překladu, během samotné práce př̀kladatele. Ve vysoce formalizovaném diskurzu LTS či institucionálního překladu patři mezi podstatný faktor, který překladatelská rozhodnutí ovlivňuje, překladové př́ručky a stylistické pokyny. Téma příruček v překladovém/překladatelském procesu stále zůstává z velké části neprobádané, a to jak v oblasti české translatologie, tak translatologie zahraniční.

Pro zkoumání překladových př́ruček a stylistických pokynů je podstatná otázka, co ovlivňuje volbu $\mathrm{z}$ množiny různých alternativ (slovy Levého: $\mathrm{z}$ paradigmatu ${ }^{2}$ ). Podle Levého je taková volba dána instrukcemi. Tyto instrukce nazývá dále ve svém pojednání již specificky výběrovými instrukcemi. ${ }^{3}$ Uvedenou kategorií se budeme zabývat níže; na tomto místě je však vhodné podotknout, že Levý se ve svém textu (1971) zmiňuje o mnoha různých instrukcích a faktorech, které ovlivňují překladový/překladatelský proces, avšak nepředkládá tyto kategorie v systematizované podobě (některé ani jako takové explicitně neoznačuje, nýbrž jejich distinkce vyplyne až z bližšího studia jeho textu). Takové vesměs roztroušené zmínky zejména $\mathrm{z}$ textu Geneze a recepce literárního díla ${ }^{4}$ se tak pokusíme usoustavnit a formalizovat do podoby modelu.

Přítomné pojednání je rozděleno na dva hlavní tematické celky. První představuje rozbor Levého konceptu překladu jako rozhodovacího procesu a zahrnuje formalizaci ${ }^{5}$ tohoto konceptu do podoby modelu. Druhý oddíl pak takto vytvořený model aplikuje na oblast institucionálního překladu, konkrétně pak jako návrh k systematizaci různých typů překladových př́ruček a stylistických pokynů (ani jedno, ani druhé, zdá se, v podobném rozsahu dosud v translatologii učiněno nebylo).

Aplikace modelu ukáže šíri jeho tematického rozsahu, která je v oblasti institucionálního překladu obzvlášt žádoucí. Na jednu stranu je překladových prríruček u některých institucí velké množství, a byt' byly v prrípadě jedné instituce popsány kvantitativně́, příručky nejsou blíže utříděny ani podrobně charakterizovány. Na druhou stranu takové př́ručky často regulují téměř vše, co se týče překladu jako procesu (formát souborů a manipulace s nimi, komunikace účastníků, rešeršní zdroje, uplatněné technologie apod.), a stylistické pokyny pak mnoho z toho, jak má vypadat překlad jako produkt (jazyková kritéria, struktura/formátování textu apod.). Obě zaměření jsou pochopitelně provázaná a mnohdy specifikovaná ve společných příručkách.

2 Paradigma Levý definuje jako „soubor možných alternativ“ (1971: 73), jež jsou pro volbu k dispozici, či jako „množin[u] prvkủ vyhovujících jisté instrukci“ (s. 75).

3 Či též instrukcemi pro výběr. Dodejme, že výběrové instrukce se dotýkají skutečně výběru alternativ. Vedle výběrových instrukcí Levý uvádí ještě tzv. definiční instrukce. Ty jsou „formou paradigmatu a paradigma je jejím obsahem“ (srov. 1971: 75), jinými slovy definiční instrukce určují dané paradigma.

4 Levý 1971: 71nn.

5 Tento postup, zdá se, není proti logice Levého úvah o rozhodovacím procesu, vždyt’ i o kódu (tj. systému definičních instrukcí) literárního díla uvádí, že je „dokonale formalizovatelným souborem pravidel“ (Levý 1971: 99, zvýraznění přidáno).

6 Srov. Svoboda 2017. 


\section{Stav rozpracovanosti problematiky}

Zde je nejprve shrnut dosavadní výzkum pro oba tematické celky, jak problematiku rozhodovacího procesu, tak institucionálního překladu.

\subsection{Literatura k Levého pojetí rozhodovacího procesu}

Pojem rozhodovacího procesu $\mathrm{v}$ překladu patří $\mathrm{k}$ základním pojmům translatologie. Je nasnadě, že zkoumat rozhodovací proces v oblasti institucionálního překladu je možné též mnoha jinými způsoby než aplikací již více než 50 let starého př́stupu od J. Levého. Za současných podmínek je tak možné použít řadu modelů či nástrojů mapujících kognitivní postupy na straně překladatelů. Důvod, proč zde byl zvolen právě př́stup J. Levého, spočívá v okolnosti, že Levého koncept je veskrze otevřený a umožňuje, aby byl formalizován a následně i relativně snadno aplikován při kategorizaci překladových př́ruček a stylistických pokynů.

Uchopení rozhodovacího procesu Jiřím Levým se stalo součástí kánonu základní translatologické bibliografie, přičemž se na tento koncept dlouhodobě odkazuje ${ }^{7}$ (nebo, bohužel, také neodkazuje ${ }^{8}$ ). V německy mluvících zemích se jednalo o veskrze nosné téma raných translatologických pojednání, zabývali se jím např. teoretikové K. Reißová, P. Kußmaul, W. Wilss či G. Gerzymisch-Arbogastová, ${ }^{9}$ přičemž se lze domnívat, že tato pojednání výrazně ovlivnil J. Levý a jeho publikace z roku 1969 (tedy Umění prèekladu $v$ němčině).

Levého pojetí samotné bylo podrobeno akademické reflexi napřs. v publikacích R. van Den Broecka či Z. Jettmarové. ${ }^{10}$ B. Englund-Dimitrová ve své publikaci Expertise and Explicitation in the Translation Process (2005) hojně pracuje s Levého pojmy, jeho koncept překladu jako rozhodovacího procesu však blíže nerozebírá.

Levého pojetí bylo dále aplikováno na různé diskurzy, včetně např̀. práce s korpusy. ${ }^{11}$ Pro tuto stat je podstatná aplikace Levého konceptu na neliterární překlad a zde je z poslední doby relevantní publikace V. Obdržálkové z r. 2016. ${ }^{12} \mathrm{~V}$ př́tomném pojednání však rozpracujeme Levého model podrobněji, formalizujeme jej a aplikujeme na oblast institucionálního překladu. $V$ centru naší pozornosti tak nejsou překladatelské problé-

7 Např́klad rešerše na portálu Bitra (dostupné z: https://aplicacionesua.cpd.ua.es/tra_int/usu/buscar .asp?idioma=en, cit. 23. 5. 2019) ukazuje, že dílo Levý 1967 je průběžně citováno od roku 1975 a k aktuálnímu datu (květen 2019) je zde evidováno přesně 100 citací. Zjevně se však nejedná o vyčerpávající výčet ohlasů, zde je uvádíme pouze jako doprovodný fakt.

8 Srov. Touryho formulaci „, [...] translational norms are intersubjective factors influencing, and to a large extent even determining, the choice of translational solutions [...] they act as a model, in accordance with which translations are actually formulated [...] [E]very model supplying performance instructions may be said to act as a restricting factor on the selection of TL material [...] it opens up certain options while at the same time it closes others" (1980: 64, zvýraznění přidáno), která velmi nápadně koresponduje s Levého pojetím a terminologií, (srov. pojmy intersubjektivní faktor, instrukce (pro výběr) či pojetí volby, která omezuje výběr v následném kroku).

9 Srov. Reiß 1976/1993, 1981/2000, Kußmaul 1986/1994, Wilss 1988 či 1998, Gerzymisch-Arbogastová 1996.

10 Van Den Broeck 1998, Jettmarová 2016.

11 Srov. Čermák 2016.

12 Obdržálková, V. Translation as a decision-making process: an application of the model proposed by Jiří Levý to translation into a non-mother tongue. 
my a strategie jejich řešení, nýbrž (obecná) taxonomie kategorií rozhodovacího procesu. Jinými slovy, zde se problematikou zabýváme v obecné rovině, nikoli v souvislosti s experimentem, přičemž zde učiněný rozbor pak dále poslouží k (meta)teoretické aplikaci.

\subsection{Literatura k rozhodovacímu procesu a k pravidlům, jež tento proces určují}

Pokud jde o problematiku pravidel, či přesněji konvencí (avšak mimo institucionální rovinu), v českém lingvistickém diskurzu se jí zabýval už V. Mathesius. Publikoval obhajobu konvencí, ale zároveň pléduje pro uvážlivý způsob nakládání s nimi: „Konvence jako soustava ustálených zvyků je nepostradatelná pro ekonomii života [...], ale život by ztratil svůj půvab a svou dynamičnost, kdyby konvence a konvenčnost se staly absolutními vládkyněmi." 13

Pro oblast rozhodovacího procesu a pravidel je k dispozici unikátní (a v kontextu institucionálního překladu doposud nezohledněnýl${ }^{14}$ ) příspěvek ke zkoumání komunikačního procesu - teorie tzv. optimalizace komunikace (Kommunikationsoptimierung) K. Schuberta. Bližší popis tohoto př́istupu ponecháváme stranou, zmíníme však alespoň obecnou pasáž, kde autor propojuje překlad, rozhodovací proces a otázku pravidel:

Jestliže komunikace [včetně překladu], a to i komunikace odborná, je řízeným rozhodovacím procesem [gelenkter Entscheidungsprozess] a pokud optimalizace komunikace je určitou formou vědomých zásahů [do tohoto procesu], pak lze konstatovat, že možnosti takového zasahování spočívají v tom, co se v [jiných] publikacích označuje jako pravidla [Regeln]. (Schubert 2009: 126, překl. a zvýraznění T. S.)

Dále Schubert podrobněji rozvádí kritéria rozhodovacího procesu, a to takto: Rozhodnutí spočívá ve volbě řešení z určité množiny možných řešení (prostor rozhodnutí, Entscheidungsraum). Rozhodovací proces je řetězcem rozhodnutí týkajících se výběru. Každé potenciální řešení se vyznačuje určitými distinktivními vlastnostmi či charakteristickými atributy rozhodnutí (Entscheidungsmerkmale). Rozhodování probíhá pomocí rozhodovacích kritérií (Entscheidungskriterien) a ta jsou pak sama podřízena pravidlìm (Entscheidungsregeln). „Vlastní rozhodovací proces probíhá jako vyvažování [Abgleich] mezi kritérii pravidel a charakteristickými atributy různých řešení. Ucelený soubor pravidel je pak rozhodovacím mechanismem. "15 Schubert pak v dalším pojednání namísto pojmu pravidla (Regeln) používá termín „určující vlivy“ (lenkende Einflüsse).

Dále autor vyjmenovává, čeho se dané určující vlivy (m. j. pokyny) mohou týkat, a rovněž upřesňuje, že autoritou, která pravidla či specifikace vydává, je zadavatel překladu:

Při [...] odborném překladu je běžné, že zadavatelé př̀edkládají nejrůznější pokyny, které se týkají produktu, jenž má vzniknout, zdrojů, jež se při tvorbě produktu mají použít, a případných pomůcek či dalších podmínek. Tím zasahují do komunikačního rozhodovacího procesu [...] překladatelů. (Schubert 2009: 131, překl. a zvýraznění T. S.)

13 Mathesius 1982: 371.

14 Pravděpodobně proto, že právě není zpracován z pozice translatologie, nýbrž teorie komunikace.

15 Schubert 2007: 245, cit. dle Schubert 2009: 126, překlad T. S., kurziva původní. 
Blízké Levého (popř́padě našemu zde prezentovanému) pojednání je pak i Schubertovo rozlišení vnitřního rozhodovacího procesu (který zahrnuje mentální, kognitivní a myšlenkové postupy) a vnějš́ího procesu, jenž zahrnuje to, co je patrné pro osobu stojící mimo daný proces. Vnější proces se také běžně označuje jako „workflow“.

\subsection{Literatura k institucionálnímu překladu}

O problematice institucionálního překladu se $\mathrm{v}$ česky ${ }^{16}$ psané odborné literatuře pojednává zatím spíse sporadicky. Ve speciálním smyslu (tedy pokud jde o instituce nadnárodní, zejména pak EU) je u nás patrně nejstarším pojednáním publikace Obrová a Pelka 2001. I současný diskurz (zejména kvalifikační práce na univerzitách, nejčastěji zkoumající terminologický aspekt) se týká primárně evropského kontextu (přesněji: výzkumu situace u institucí a orgánů EU), přičemž často chybí zasazení do širších souvislostí podoboru institucionálního překladu v rámci translatologie. ${ }^{17}$ Publikovaná akademická pojednání jsou nepočetná. Totéž pak platí i o specifickém rysu institucionálního překladu, jímž se zde blíže zabýváme, a tedy o překladových příručkách a stylistických pokynech.

Nejprve upřesníme pojem institucionální překlad. Zde nejlépe poslouží následující definice:

V nejširším smyslu lze jako institucionální překlad označit jakýkoli překlad, který probíhá $v$ institucionálním kontextu, přičemž instituci, jež překlad zajištuje, lze označit za překládající instituci [translating institution]. (Schäffner a kol. 2014: 493, překl. a zvýraznění T. S.)

Existují samozřejmě různé typy institucí, v jejichž kontextu se realizují př̌eklady, například komerční, neziskové, nadnárodní, mezinárodní, státní, vládní, nevládní atd. Pokud jde o institucionální překlad u nadnárodních institucí, platí zde, že překladové prŕručky a stylistické pokyny jsou jedním z jeho stěžejních rysů. ${ }^{18}$ Při zkoumání vnitrostátního institucionálního překladu se však ukázalo, ${ }^{19}$ že na této úrovni již daný rys (tedy využívání překladových př́ruček a stylistických pokynů) zdaleka není konstitutivní. $\mathrm{Z}$ tohoto zjištění pak vyplynul požadavek pokračovat ve výzkumu a dále zpřesňovat definici institucionálního překladu.

\subsection{Literatura k institucionálnímu překladu jako rozhodovacímu procesu}

Pro současné pojednání je též důležitý pohled na procesuální stránku institucionálního překladu. O procesu v širším slova smyslu (workflow) pojednávají např. publikace Evropská komise 2017, Biel 2014, Bednárová-Gibová 2016 (dva předešlé zdroje převážně

16 Detailnější pojednání o mezinárodní sekundární literatuře k tématu institucionálního překladu je, $\mathrm{z}$ poslední doby, $\mathrm{k}$ dispozici např. $\mathrm{v}$ publikacích autora tohoto př́spěvku (viz seznam literatury).

17 Výjimkou je diplomová/dizertační práce J. Hanzla (2006).

18 Srov. např. Koskinen 2008: 18, Halverson 2008: 343 či Kang 2009: 142. Schäffnerová pak uvádí: „Institucionální překlad je typicky kolektivní, anonymní a standardizovaný.“ (2014: 494; překl. a zvýraznění T. S.)

19 Viz Svoboda 2018. 
s důrazem na překlad právních textů u EU), Svoboda 2008 či již poněkud starší zdroj Drugan 2004.

Ještě důležitější je zde však pohled na rozhodovací proces na straně překladatele, tedy na překladatelský proces $\mathrm{v}$ užším slova smyslu. Je pozoruhodné, že už v jedné z prvních publikací zaměřených specificky na institucionální překlad se objevuje zmínka o rozhodovacím procesu: Překladatelská rozhodnutí (translational decisions) jsou do značné míry určována cíli instituce, v jejímž rámci překladatel pracuje (srov. Mossop 1990: 343).

\subsection{Literatura k institucionálnímu překladu, rozhodovacímu procesu a překladovým príručkám či stylistickým pokynům}

Této již poměrně speciální oblasti se dotýká K. Koskinenová či A. Feliciová. ${ }^{20}$ Postupy u konkrétních institucí pak zkoumal výzkum prezentovaný v publikaci Schäffnerové a kol. Zde jsou tyto postupy kontrastovány s mírou svobody/volnosti či kreativitou:

Ačkoli někdy mají překladatelé [u Evropské centrální banky] prostor pro kreativitu (např. při překladu nových termínů), obecně lze říci, že na straně překladatelů jsou pravomoc a volnost omezené, nebot překladatelé musejí dodržovat postupy dané instituce. (2014: 503, př̀kl. a zvýraznění T. S.) $)^{21}$

Podnětné je pojednání Ji-Hae Kanga, podle nějž rozhodnutí překladatelů v institucionálním prostředí jsou institucí („institučním řádem“) řízena, avšak takové pokyny nemusejí vždy vést ke kýžené harmonizaci projevu instituce:

[I v těch] př́padech, kdy instituční řád jasně podmiňuje úkony, rozhodnutí, zpusob práce či postupy konkrétních překladatelů, překladové/překladatelské postupy v institucích nejsou ani zdaleka jednotné. (2014: 475, překl. a zvýraznění T. S.)

Institucionální překlad, rozhodovací proces a konkrétně už i specifikace propojují Atari a Al-Sharafi. Ačkoli pojednávají o překladu v akademickém prostředí, metodologický př́ístup je inspirativní, zahrnuje totiž následující:

[Naše] analýza - jejímž prostřednictvím se zkoumají překladatelská rozhodnutí a odpovídající institucionální normy - posuzuje dopad institucionálních norem na rozhodnutí překladatelů [...]. Z dat získaných v rámci uvedené případové studie vyplývá, že instituční normy platné v akademickém prostředí vytvářejí tlak na rozhodnutí překladatele a omezují je, což, obecně vzato, má za následek doslovný cílový text s menším sklonem k idiomatičnosti jazyka. (2012: 195, překl. a zvýraznění T. S.)

Jak je patrné, otázka vztahu překladových příruček či stylistických pokynů, rozhodovacího procesu a institucionálního překladu byla dosud nastíněna v nemnoha pojedná-

20 Srov. Koskinen 2000: 50, Felici 2010: 101.

21 To, do jaké míry se překladatelé mohou rozhodovat volně/svobodně (vezme-li se v potaz skutečnost, že jsou ovlivňováni institučními postupy), popisuje publikace na jiném místě jako kritérium činitelskosti - „agency“; srov. s. 509. 
ních. Níže se tedy pokusíme problematiku blíže osvětlit. V následujícím oddílu nejprve podrobně popíšeme, systematizujeme a formalizujeme Levého pojetí rozhodovacího procesu a získaný model potom aplikujeme na oblast institucionálního překladu obecně a překladových př́ruček a stylistických pokynů zvláště.

\section{Rozbor a formalizace Levého pojetí rozhodovacího procesu}

Jak uvádí Z. Jettmarová, ${ }^{22}$ Levý svůj koncept rozhodovacího procesu představil v roce 1966, na konferenci v Moskvě. Anglické znění pojednání (Levý 1967) bylo publikováno v následujícím roce, ve sborníku To Honor Roman Jakobson. O další čtyři roky později pak vyšla rozšírená česká verze článku, a to ve sborníku Bude literární věda exaktní vědou? (Levý 1971), konkrétně v oddílu Geneze a recepce literárního díla. Níže vycházíme z publikace Levý 1971, avšak přihlédneme též k původnímu pojednání Levý 1967.

\subsection{Překladatelské instrukce dle Jiř́ho Levého a jejich rozlišení}

Zde shrnujeme distinkce ${ }^{23}$ dokreslující rozhodovací proces překladu, jež J. Levý uvedl (at̉ už explicitně, či implicitně) ve svém díle Levý 1971. O rozhodovacím procesu se Levý vyjadřuje i ve svých dřívějších pracích, takové zmínky však v námi sestavené taxonomii rozhodovacích distinkcí zohledněny nebudou, protože to přesahuje zaměření přítomného pojednání.

V souvislosti s rozhodovacím procesem je předně pro výzkum překladových příruček a stylistických pokynů vhodné zmínit Levého pohled na překladatelský proces v užším slova smyslu, včetně distinkce na recepční proces ${ }^{24}$ a (tvưrčí) proces geneze. Některá rozhodnutí se týkají recepce, jiná geneze. V zájmu přehlednosti tuto dichotomii do modelu ale nepromítáme. Pro naše zkoumání je podstatná otázka, na jakých rovinách ${ }^{25}$ dochází $\mathrm{k}$ volbě $\mathrm{z}$ množiny různých alternativ (slovy Levého tedy: $\mathrm{z}$ paradigmatu) v rámci široce pojatého rozhodovacího procesu. Levý pak specifikuje různé instrukce či kategorie, $\mathrm{z}$ nichž jsme vytvořili následující typologii o desíti distinkcích:26

\section{Distinkce č. 1: Volba díla pro překlad}

- Přeložit jisté dílo (čili nepreložit dílo jiné), nebo

- přeložit jiné dílo.

22 Jettmarová 2009: 48.

23 Distinkce též formalizujeme a usoustavňujeme do grafické podoby, viz obr. č. 2 níže.

24 Recepcí Levý rozumí „volb[u] mezi možnými významy slova“ (Levý 1971: 86) či „volb[u] ze [...] stylu i ideologie autora“ (Levý 1971: 74), genezí pak výběr slov, která danému významu přibližně odpovídají v cílovém jazyku.

25 Již zde lze předběžně konstatovat, že pro Levého se taková rozhodnutí odehrávají na různých strukturních rovinách, od úrovně napřs. slova až po úroveň díla.

26 Jak již bylo řečeno, Levý distinkce neprezentuje v takto systematizované podobě, naopak, různé distinkce a kategorie jsou v kapitole Geneze a recepce literárního díla různě roztroušené, zmiňované průběžně. 
Zde se jedná o distinkci, kterou Levý uvádí jen na okraj svého pojednání o rozhodovacím procesu (zmiňuje ji v poznámce pod čarou): „Primární rozhodnutí je samozřejmě volba díla pro překlad [...].“ Jde nepochybně o složitou strategii, „jejiž pravidla ovládají hlavně nakladatelé“. ${ }^{27}$

Na druhé nejvyšší př́íce hierarchie faktorů, které ovlivňují překladatelský proces ${ }^{28}$, se podle Levého nachází jednak distinkce instrukcí samotných a jednak jejich uspořádání:

\section{Distinkce č. 2: Bazální úroveň vs. metaúroveň instrukcí/paradigmat \\ - Metaúroveñ instrukcí/paradigmat, jež se týká jejich usporádání (či pravidel jejich řazeníl členèní), \\ - bazální úroveň instrukcí/paradigmat ${ }^{29}$.}

Tato distinkce je v Levého pojednání jen naznačena, a to jednak když se zamýšlí nad tím, že existují určité faktory ovlivňující překladatelský rozhodovací proces, popř́ípadě nad tím, jaké jsou, a jednak když hovoří o vztahu mezi instrukcemi/paradigmaty (a nazývá jej „syntaxí"):

[R]ozhodovací proces v překladu má vlastně strukturu jazyka. Má svůj [...] soubor jednotek definovaných sémanticky (tedy vztahem k označovanému); má svou syntaxi, tj. pravidla pro kombinování těchto jednotek - at již jednotkou rozumíme paradigma nebo instrukci [...a a] má i třetí sémiotický rozměr, tj. pragmatický. (1971: 86, zvýraznění přidáno)

\section{Distinkce č. 3: Subsumpce definičních a výběrových instrukcí}

- Definiční instrukce se stává nadřazenou instrukcí (množinou, instrukcí vyššího rádu),

- výběrové instrukce jsou pak podmnožinou (jsou instrukcí nižšího řádu; až potenciálně na úroveň jednočlenného paradigmatu $\left.{ }^{30}\right)$.

Instrukce definiční a instrukce výběrové (viz níže, distinkce č. 9) jsou provázané:

Mezi instrukcí definiční a výběrovou je vztah subsumpce: tj. vztah mezi množinou a podmnožinou, systémem a podsystémem, kategorií a jejím členem. $Z$ množiny alternativ ohraničené definiční instrukcí vyčleňuje výběrová instrukce podmnožinu, pro niž se sama stává instrukcí definiční - a tak dále - až se dojde $\mathrm{k}$ jednočlennému paradigmatu. (Levý 1971: 77, zvýraznění přidáno)

27 Srov. Levý 1971: pozn. pod čarou č. 3 na s. 73. Dodejme, že uvádí pouze pozitivní distinkci „volba díla pro překlad“. Doplnění, že se jedná o volbu přeložit určité dílo, z čehož jako důsledek v daném okamžiku vyplývá nepřeložení díla jiného (čili tzv. princip non-translation), připojujeme sami. Levý tuto distinkci naznačuje už ve svém Umění překladu (Levý 1963/1998): „Při překládání - a to [...] především při rozhodování, co přeložit - je někdy třeba brát v úvahu také to, že oblast literárních žánrů [...] se ve všech literaturách nekryje.“ (Levý 1963/1998: 226n, zvýraznění přidáno)

28 Levý různé distinkce uvádí jako př́íklady rozhodování při volbě např. lexikální jednotky, ale dodává, že platí i pro prvky „vyššího řádu“ (srov. 1971: 80).

29 O tomto pojmu je zde detailněji pojednáno níže, viz následující distinkce, č. 3.

30 Popř́padě tzv. „terminálního symbolu“ (výraz J. Levého, viz Levý 1971: 77). 
Levý tuto situaci znázorňuje následovně:

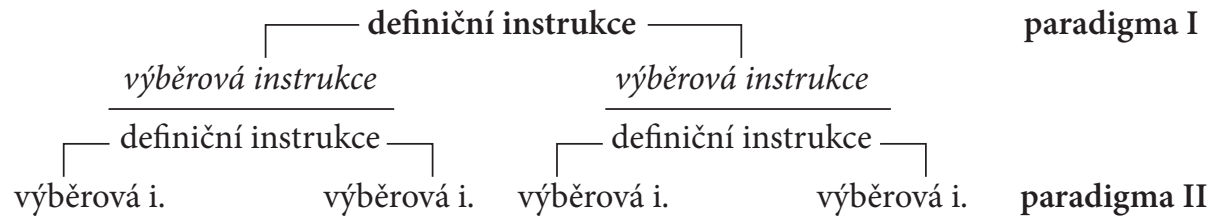

Obrázek 1. Vizualizace poměru definičních a výběrových instrukcí v překladatelském rozhodovacím procesu podle J. Levého ${ }^{31}$

Pro oblast geneze literárního díla Levý uvedenou terminologii aplikuje na dichotomii kód literárního díla vs. estetická norma: Soubor závazných instrukcí je součástí kódu (systému definičních instrukcí) daného literárního díla (Levý 1971: 99). Estetická norma je pak souborem výběrových instrukcí uvnitř jednotlivých paradigmat. Paradigma na jedné z nejvyšších úrovní překládání pak může zahrnovat rozhodování mezi typy překladových strategií, metod či postupů. ${ }^{32}$ Zároveň platí, že každé překladatelovo rozhodnutí (řešení) zároveň automaticky omezí výběr pro rozhodování v následujícím kroku. ${ }^{33}$

\section{Distinkce č. 4: (Ne)akceptace instrukcí}

- Přijetí instrukcí (či akceptace normy),

- nezohlednění instrukcí (norma neexistuje, popřípadě př́jemce je vůči instrukcím/normě indiferentni),

- negace instrukcí (či negace normy).

Jedná se o další kategorii Levým zmíněnou pouze „mimochodem“ (na s. 105). Týká se překladatelova postoje vưči tzv. „elementárním instrukcím“ (čili dobové normě), popřípadě vůči různým rovinám dobových norem, tzv. norménům. ${ }^{34}$ Levý zcela př́ípadně uvádí, že taková odezva může být trojího druhu, tedy nikoli jen přijetí, či nepřijetí (nezohlednění) takových instrukcí, nýbrž i přímo záměrná volba opačného postupu, tedy reakce negující.

\section{Distinkce č. 5: Kvantitativní vs. kvalitativní hledisko rozhodování}

Ani tato distinkce není v Levého textech uvedena explicitně, zařazujeme ji zde zejména pro účely systematizace následných distinkcí, č. 6 a 7.

31 Viz Levý 1971: 77.

32 Tuto distinkci (týkající se strategie/metody/postupu při překladu) v Levého pojednání o rozhodovacím procesu (Levý 1971) nenajdeme, ale Levý s ní pracuje ve svém starším díle, Umění překladu: „Tam, kde [...] překladatel se rozhodne mezi dvěma postupy (překlad-substituce), je jeho volba podmíněna celkovou metodou, a ta vyplývá z rázu celého díla." (Levý 1963/1998: 135, zvýraznění přidáno)

33 „Jakmile jednou byla volba provedena, stává se rozhodnutí instrukcí, jež omezuje rozsah paradigmatu, ze kterého bude prováděn výběr v dalším tahu." (Levý 1971: 92)

34 Jako př́klad zde Levý uvádí normény jako „dodržování hierarchie žánrů, rytmicko-syntaktický paralelismus, individualizace postav, individualizace prostředí, tři divadelní jednoty atd. “, srov. s. 105. 


\section{Distinkce č. 6: Kvantita rozhodnutí prekladatele oproti rozhodnutí autora originálu}

- Méně rozhodnutí oproti autorovi originálu,

- více rozhodnutí oproti autorovi originálu.

Překladatel vykonal bud' méně, nebo více rozhodnutí ve srovnání s autorem originálu. Levý toto rozhodování uvádí ve vazbě na problematiku interpretace významu slova. Pro názornost výkladu Levý uvádí příklad, kdy se při překladu $\mathrm{z}$ angličtiny (např. do ruštiny) musí upřesnit význam slovesa „to go“; v citovaném kontextu má překladatel na výběr z významů jít, jet a letět. Navíc tuto kategorii Levý propojuje s další rovinou rozhodování, a to s (ne)nutností či (ne)motivovaností takových rozhodnutí (srov. zde dvě následující distinkce, ̌̌. 7 a 8$).{ }^{35}$

\section{Distinkce č. 7: (Ne)nutnost dodatečných rozhodnutí}

- Nutná,

- nenutná rozhodnutí.

V případě více rozhodnutí oproti originálu (srov. distinkci č. 6) mohou být taková dodatečná ${ }^{36}$ rozhodnutí dvojí: nutná a nenutná. Jedná se o rozhodnutí, jimiž se překlad odklání od originálu - např. na úrovni počtu slovních ekvivalentů a jiných jazykových prvků. Nutná dodatečná rozhodnutí jsou taková, jež jsou dána jazykovým systémem.

\section{Distinkce č. 8: (Ne)motivovanost rozhodnutí \\ - Motivované, \\ - nemotivované rozhodnutí.}

Jedná se o kategorii uvedenou na s. 78 a rozšiřující distinkci č. 7. Zde Levý vysvětluje, že „[m]otivované je rozhodnutí tehdy, je-li odůvodněno kontextem (jazykovým nebo mimojazykovým)“ (s. 79). ${ }^{37}$ Široce pojatý kontext může zahrnovat „celou knihu, celé dílo autora, celou dobovou literární konvenci apod.“ (tamt.).

\section{Distinkce č. 9: Instrukce pro výběr 38}

- Objektivní (kontext),

- subjektivní (struktura lingvistické pamèti překladatele) a

- intersubjektivní rozhodnutí (dobová norma).

35 Srov. s. 78. V této souvislosti se pak Levý dále např. zamýšlí nad strukturními rozdíly jazyků.

36 Srov. tamt. Levý používá termín „nadbytečná“, který však považujeme za méně srozumitelný. Ve znění publikace Levý 1967 se používá termín „surplus decisions“. Myšlena jsou rozhodnutí učiněná „navíc“ oproti originálu.

37 Vztah (ne)nutných a (ne)motivovaných dodatečných rozhodnutí pak Levý pro úplnost uvádí do permutačního přehledu, kdy mohou existovat čtyři prrípady:
„a) nadbytečné rozhodnutí nutné a motivované;
b) nadbytečné rozhodnutí nutné a nemotivované: zde je největší možnost omylu [...];
c) nadbytečné rozhodnutí nenutné a motivované;
d) nadbytečné rozhodnuli nenutné a nemotivované; to jsme již v oblasti překladatelské libovůle, dokreslováni'“ (s. 79).
38 Jako synonymum Levý volí též označení „výběrové instrukce“. 
Zde se jedná o stěžejní instrukce ${ }^{39}$ pro vlastní rozhodovací proces na straně překladatele. K první uvedené (objektivní) instrukci Levý připojuje (již zmíněné, avšak pro nás velmi důležité) doplnění ${ }^{40}$, že kontext může být jak jazykový, tak mimojazykový.

\section{Distinkce č. 10: (Ne)uvědomělost rozhodnutí \\ - Uvědomélé, \\ - neuvědomělé rozhodnutí.}

Zmínka o těchto dvou typech rozhodnutí je v publikaci Levý 1971 jen letmá (s. 77). Tyto instrukce spadají do kategorie subjektivních rozhodnutí (srov. zde výše, distinkce č. 9). Levý je dále nerozebírá, jen konstatuje, že „[v]ýběr lexikální jednotky je řízen takovým systémem uvědomělých nebo neuvědomělých instrukcí, takže u konečného výrazu, který se objevuje v textu [...], bychom mohli rozborem zjištovat [...] strukturu jeho geneze (generativní strukturu)“(s. 77n).

Pro větší názornost jsme tyto bud' převzaté, modifikované nebo doplněné distinkce usoustavnili do přehledného modelu, který uvádíme na následující straně.

Uvedené grafické znázornění zachycuje různé stupně a typy rozhodovacího procesu $\mathrm{v}$ překladu. Jak je patrné, každá nadřazená rovina (jednotlivé distinkce s šedým podbarvením) se dále člení (zde zpravidla binárně, ve dvou případech na tř̌i kategorie). Takové členění se následně stává paradigmatickou rovinou až po úroveň konkrétního překladatelského řešení.

\subsection{Srovnání pojetí výběrových instrukcí mezi publikacemi Levý 1971 a Levý 1967}

Jiří Levý svůj koncept rozhodovacího procesu v publikaci Levý 1971 poněkud rozvinul. Pro bližší pochopení zde uvádíme srovnání mezi zněním Levý 1967 a Levý 1971. Ze srovnání vyplývá čtverý rozdíl mezi instrukcemi pro výběr (srov. zde distinkce č. 9 výše): 1) V publikaci Levý 1967 jsou jako instrukce pro výběr („selective instructions“) uvedeny instrukce objektivní („objective“) a subjektivní („subjective“, tedy např́ílad struktura překladatelovy paměti či překladatelova estetická norma - „his aesthetic standards“). Není zde uvedena třetí kategorie - tedy intersubjektivní.

2) Prvek normativnosti (zastoupený u intersubjektivních instrukcí ve znění Levý 1971) se objevuje ve znění Levý 1967 jako položka subjektivní (estetická norma překladatele).

3) V publikaci Levý 1967 se uvádí, že objektivní instrukce jsou determinovány jazykovým materiálem („linguistic material“), a nikoli kontextem (jak uvádí publikace Levý 1971).

4) V publikaci Levý 1967 není specifikováno, o jaký typ paměti se na straně překladatele (subjektivní instrukce) jedná, přičemž v publikaci Levý 1971 je upřesněno, že se jedná o pamět „lingvistickou“ (tj. jazykovou).

39 Levý tuto triádu uvedeným způsobem nepopisuje, spíše uvedené kategorie používá jako označení doplňková, srov. s. 76 .

40 Na jiných místech publikace Levý 1971; viz též výše u distinkce č. 8 . 


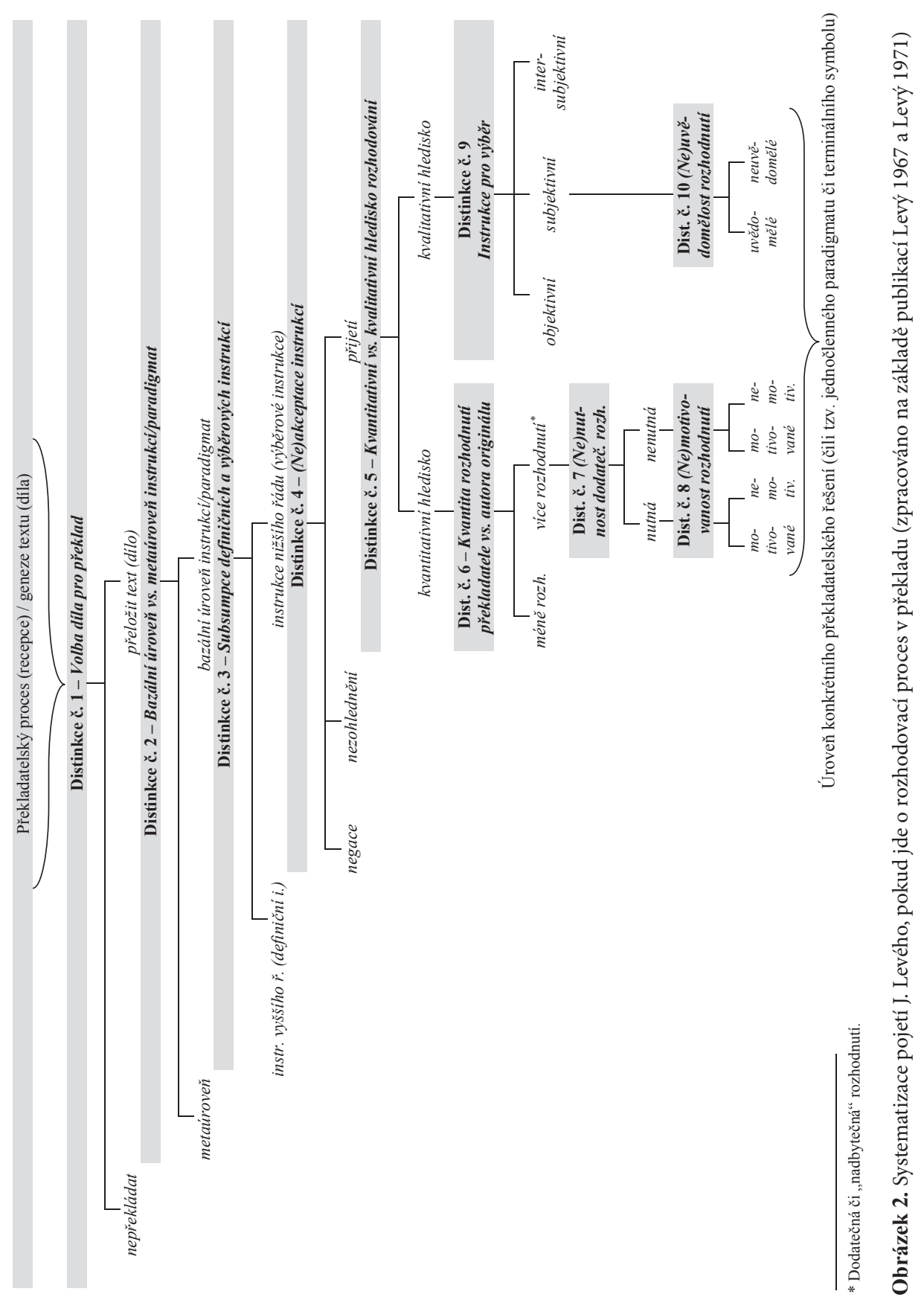


Z tohoto srovnání je zřejmé, že Levý při úpravě¹ publikace Levý 1967 do podoby, která pak vyšla jako jedna z kapitol Levý 1971, upřesnil, že otázka estetické normy se dotýká spiše roviny intersubjektivní než subjektivní. Rovněž upřesnil, že za distinktivní prvek, který ovlivňuje rozhodnutí překladatele, považuje především jazykovou pamět. Jako velmi podstatný rozdíl se jeví odlišné pojetí objektivních instrukcí: Zatímco v publikaci Levý 1967 byly tyto determinovány předně jazykovým materiálem, ve znění Levý 1971 jsou určovány primárně kontextem. ${ }^{42}$

\subsection{Dílčí shrnutí pojednání o konceptu Jiřího Levého}

Uvedené desatero distinkcí Levý neprezentuje $\mathrm{v}$ takto systematizované podobě. Naopak, různé distinkce jsou zmiňované v celé kapitole Geneze a recepce literárního díla (Levý 1971) průběžně a veskrze nespojitě. Ukazuje se však, že jednotlivé distinkce by se neměly chápat jako disparátní. Jako př́íklad lze uvést objektivní a intersubjektivní instrukce (srov. zde distinkci č. 9) a pojem kontext: Na jednom místě (s. 76) je tento pojem Levým zahrnut primárně do objektivní kategorie, avšak o tři strany dál (s. 79) je dán do př́mé souvislosti s pojmem „dobová literární konvence“, který je však jinde definován jako charakteristický prvek pro intersubjektivní kategorii. Dále je třeba připomenout, že předložený systém je velmi dynamický: „[K]onkrétní volba se zpravidla děje podle celého souboru výběrových instrukcí ${ }^{43}$ přičemž prvky tohoto souboru jsou ve vzájemném vztahu determinujícího a determinovaného člena (srov. distinkce č. 2 a 3 výše).

Zde, v oddílu třetím našeho pojednání, jsme dopodrobna představili Levého koncept rozhodovacího procesu. $\mathrm{V}$ oddílu následujícím vytvořený model aplikujeme na institucionální překlad.

\section{Aplikace Levého modelu na oblast institucionálního překladu}

Jak bylo zmíněno v úvodu, jedním ze dvou stěžejních cílů tohoto pojednání je aplikovat Levého koncept rozhodovacího procesu $\mathrm{v}$ překladu na institucionální překlad, a konkrétně na problematiku překladových př́ruček a stylistických pokynů. Před samotnou aplikací daného konceptu bylo samožrejmě na místě se nejprve ptát, zda je vůbec možná: Neprezentuje Levý svůj koncept spíše pro rozhodovací proces na těch nejnižších úrovních rozhodování či jen v souvislosti s porozuměním výchozímu textu? Bude možné použít model původně vytvořený pro literární překlad nyní na oblast překladu neliterárního? Domníváme se, že aplikace možná je. Jednak již podobné pokusy veskrze úspěšně proběhly (viz přehled stavu výzkumu výše), jednak se podobná generalizace a následná

41 Patrně tak činil již velmi krátce před svou smrtí (J. Levý zemřel v lednu 1967). Pojednání Translation as a decision process (Levý 1967) vyšlo již s největší pravděpodobností posmrtně, rukopis však jistě Levý odevzdával nedlouho po moskevské konferenci, kde př́spěvek prezentoval (v roce 1966). České (rozpracované) znění tak patrně upravoval na samém sklonku života.

$42 \mathrm{Na}$ jiném místě uvádí explicitně: „„[I]nstrukce [...] určující, kterou z [...] alternativ volit [...,] plyne z kontextu [...]“" (Levý 1971: 73, kurziva původní).

43 Levý 1971: 76, zvýraznění přidáno. V publikaci Levý 1967: 78 je použita formulace „system of [...] instructions". 
aplikace (a to i na nejvyšší roviny rozhodovacího procesu) zdají být v logice Levého uvažování. Sice uváděl, že příklady v jeho pojednání se dotýkají jen určité dílčí roviny (např̀. volby slov), ihned však na více místech dodává, že lze uvažovat o rozhodování na úrovni „vyšších celkü“, „znaků vyššího řádu“ apod. ${ }^{44}$

Rozhodovací proces překladatele je řízen mnoha aspekty, omezeními a specifikacemi. To platí jak pro překladatele textů literárních, tak neliterárních. Předpokládáme-li pak, že jednou z hlavních charakteristik institucionálního překladu je právě podřízenost pravidlům ovlivňujícím překladatelská rozhodnutí (viz zde výše, oddíl 2), je nasnadě, že rozpracování Levého úvah může být přínosem právě pro oblast institucionálního překladu, protože ten podléhá regulaci snad nejvíce ze všech oblastí překladatelské činnosti.

Dalším důvodem aplikace je, že Levý v úvahách o rozhodovacím procesu pracuje s teorií her, kde pravidla jsou konstitutivním prvkem:

Hra je popsána systémem pravidel, která mají určit formální strukturu a která určují chování jednotlivců nebo skupin nazývaných hráči... Pravidla zaručují, že hra bude konečnou posloupností tahů, prováděných v určitém pořadí, a popisují každý tah. (Levý 1971: 90, zvýraznění přidáno; Levý zde cituje D. Blackwella a M. A. Girshicka)

Z kapacitních důvodů aplikujeme výše uvedený model spíše výběrově (nezmiňujeme zde všech deset vytyčených distinkcí) a činíme tak spíše ilustrativně za pomoci šesti překladových příruček či stylistických pokynů uplatňovaných u tří typů různých institucí: nadnárodní instituce (Evropská komise, konkrétně Generální ředitelství pro překlady, a projekt terminologické databáze IATE), neziskové organizace či projekty (TED a Wikipedie) a komerční instituce (jazyková agentura a překladatelský portál). ${ }^{45}$ Pro každou oblast volíme po dvou příručkách.

Výše jsme konstatovali, že překladové př́ručky a stylistické pokyny se zpravidla vytvářejí proto, aby regulovaly jak recepci, tak genezi textu (v našem modelu se jedná o distinkci „nulté“ úrovně, ještě před distinkcí č. 1). Příkladem prvního typu takových překladových příruček může být manuál Standardy pro překladatele ${ }^{46}$ jedné pražské jazykové agentury, př́lkladem druhého typu pak pokyny Guidelines ${ }^{47}$ projektu TED. Navíc fakt, že Levý o problematice rozhodovacího procesu pojednává i v souvislosti s původním tvořením, a nikoli jen s překladem, shodou okolností představuje vhodné přemostění mezi oblastí literárního překladu (srov. Levý) a oblastí institucionálního překladu (naše

44 Srov. Levý 1971: 80 a na dalších místech.

45 U dvou posledně jmenovaných kategorií se jedná o šířeji pojatou definici institucionálního překladu, a tedy spíše o subjekty organizující překlady, nikoli o „překládající“ instituce, které samy promlouvají prostřednictvím překladů.

46 Srov. např. tuto pasáž: „V případě pochybností o správném porozumění výchozímu textu překladatel kontaktuje klienta a zajistí si vysvětlení nejasností“, in: Standardy pro prekladatele agentury Channel Crossings, dostupné z: https://www.chc.cz/cs/download/dokumenty_ke_stazeni/standardy.pdf (cit. 4. 6. 2019, zvýraznění přidáno).

47 Srov. např. tuto pasáž: „Instead of a word-for-word translation, try finding a similar expression in the target language. If no equivalent exists, opt for the translation that readers will find least confusing [...]", in: TED Guidelines, dostupné z: https://www.ted.com/participate/translate/guidelines (cit. 4. 6. 2019, zvýraznění přidáno). 
aplikace). Důvodem je známé pojetí legislativních textů u institucí (konkrétně u institucí/ orgánů EU) nikoli jako překladů, nýbrž jakožto textů s platností originálu. ${ }^{48}$

Jako příklad příručky ovlivňující překladatelský proces podle rozhodovací distinkce č. 1 (Volba díla ${ }^{49}$ pro preklad) mohou posloužit pokyny pro překlad článků na Wikipedii ${ }^{50}$, jiným prŕkladem jsou pokyny platformy Proz.com. ${ }^{51}$ Pozoruhodně případná je aplikace distinkce č. 2 (Bazální úroveň vs. metaúroveň instrukcí/paradigmat), kdy v oblasti institucionálního překladu (a prozatím nikde jinde ve sféře překladatelské činnosti) byla prokázána ${ }^{52}$ existence nejen překladových pokynů, ale i př́ruček, jak dané pokyny používat (např. jaká je jejich hierarchie z hlediska závaznosti) - srov. příručku Hierarchie der Leitfäden für die Abfassung von Rechtstexten německého jazykového oddělení při Generálním ředitelství pro překlady Evropské komise. ${ }^{53}$

U distinkce č. 3 (Subsumpce paradigmat a instrukcí) lze rozvinout následující úvahu: Je-li pro Levého paradigma souborem prvků, z nějž lze během rozhodování při překladu volit (tedy množinou různých alternativ), pak v oblasti institucionálního překladu by takovými paradigmatickými množinami mohla být závazná terminologie, ale i soubor závazných či doporučených formulací v překladové paměti (databázi) určité instituce, či dokonce celý korpus (výchozích i) přeložených textů (např. acquis communautaire v kontextu evropských překladů).

Jak bylo konstatováno výše, Levý uvádí, že rozhodovací proces při překládání sestává $\mathrm{z}$ různých paradigmat. Paradigma nadřazené může obsahovat více variant, jemu nadřazené paradigma je opět členěno na více (ale i méně) variant atd. Paradigma nejnižší roviny (na úrovni konkrétního textového zachycení určitého překladového řešení) naopak zahrnuje už jen jediný prvek množiny, konkrétní realizaci (tedy např. vytištěné slovo či grafický prvek). U vysoce normalizovaných diskurzů (zejména tedy v oblasti institucionálního překladu) lze předpokládat, že cílem pokynů/specifikací je právě zúžit ${ }^{54}$ paradigma, z nějž překladatel volí alternativy. Ideálem takovýchto diskurzů by tedy teoreticky mohlo být zajistit u co největšího počtu paradigmat co nejnižší počet variant -

48 Srov. např. Biel 2014.

49 Pro účely lepší provázanosti předchozího teoretického pojednání a zde uvedené aplikační pasáže ponecháváme pưvodní Levého terminologii, kdy pro překládané komunikáty používá výraz dílo (byt pro oblast neliterárního překladu by byl vhodnější výraz text).

50 Srov. stránku WikiProjekt Překlad, https://cs.wikipedia.org/wiki/Wikipedie:WikiProjekt_P\%C5\%99 eklad (cit. 4. 6. 2019), obsahující rozcestník k článkům, jež je potřeba přeložit, a dokonce odkaz na automatický nástroj WQS, který na Wikipedii „umožňuje vyhledávat [...] články k překladu podle různých podmínek“.

51 Srov. např. tuto pasáž: „Professional translators [...] accept only work that they have the knowledge, resources and time to perform in line with agreed-upon terms", viz https://www.proz.com/professional -guidelines (cit. 4. 6. 2019).

52 Srov. Svoboda (2013).

53 Anglický název př́ručky: Using style guides - in what order?, viz https://ec.europa.eu/info/sites/info /files/using_style_guides_german_de.pdf (cit. 4. 6. 2019).

54 K tomu srov. Levý 1971: 74: „[J] $]$ de o volbu ze souboru možných významů slova, motivů, různých pojetí charakteru, stylu i ideologie autora. Přitom tato volba je tím zúženější [...], čím jsou situace přesnější, tj. čím jednoznačnější je [...] kontext" (zvýraznění přidáno). Levý dodává, že díky kontextu je takový překlad se zúženou možností volby snazší. Zde lze myšlenku rozvinout dále, že totiž rozhodování samo bude pro překladatele jistě snazší, ovšem pokud daná pravidla zná. Pokud naopak pravidla např. kvůli nedostatečné praxi ještě nemá zvnitřněná, musí se s nimi rámcově seznámit před překladem anebo v jeho průběhu. To - opět např. v souvislosti s institucionálním překladem - vyžaduje značné úsilí, protože takových příruček/pravidel je velké množství (desítky). 
jinými slovy redukovat výběr na co nejmenší počet členů podmnožiny. V ideálním (hypotetickém) případě by tedy všichni překládali zcela jednotně, stejně. Takový scénář lze pak vyjádřit takto:

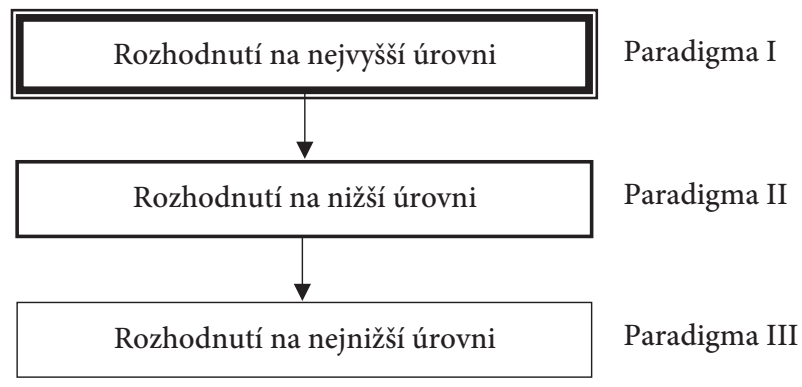

Obrázek 3. Vizualizace ideálního poměru definičních a výběrových instrukcí v překladatelském rozhodovacím procesu v kontextu vysoce normalizovaných diskurzů (rozhodování je přímočaré, alternativy nejsou k dispozici)

Překládající instituce si v praxi takový cíl ani nekladou (alespoň tak nečiní explicitně), navíc je utopický. ${ }^{55}$ I ve vysoce normalizovaném prostředí institucionálního překladu totiž platí, že kolik je překladateli̊, tolik je výsledných překladových variant. ${ }^{56}$

Pozoruhodný homogenizační (nivelizační) efekt na formulační rovině však v poslední době má využívání strojově přeloženého polotovaru jako výchozího jazykového materiálu pro vytvoření plnohodnotného translátu (při tzv. posteditaci). Opětovně se tak ukazuje aktuálnost myšlenky implementovat překladové příručky a stylistické pokyny do fáze strojového předpřekladu. ${ }^{57}$ Takové propojení strojového překladu s formalizovanými/ automatizovanými příručkami ${ }^{58}$ by nutně nemuselo znamenat zúžení „manévrovacího prostoru“ pro překladatele, protože by z překladového/rozhodovacího procesu pouze eli-

$55 \mathrm{Z}$ historie je známý snad jediný případ takové shody, a to překlad Septuaginty, kde se však patrně jedná o určité mýtické podání. (Na druhou stranu překlad Septuaginty, tak jako většina ostatních biblických překladů, je bezesporu navýsost vhodným př́kladem překladového projektu $\mathrm{v}$ - široce pojaté - oblasti institucionálního překladu.) Obecně tedy platí, že u každého typu překladu je ve větší či menší míře př́tomen prostor volby, překlad nebývá pravidlům podřízen bezezbytku: „Překlad, bez ohledu na žánr, předpokládá řadu př́padủ, kdy překladatel činí volbu, aniž by daná varianta byla předem dána." (Ljudskanov 1980: 137-9; cit. dle: Alexieva 1998, překl. T. S.)

56 Z pozorování vyplývá, že i v oblasti institucionálního překladu dochází $\mathrm{k}$ situacím, jež se zdánlivě rozcházejí s výše uvedeným utopickým postulátem. Autor tohoto pojednání se na základě vlastní zkušenosti (empirické studie v tomto směru zatím schází) domnívá, že nap̌r. př̌ekladatelé německého překladatelského oddělení Generálního ředitelství pro překlady Evropské komise volí specifickou strategii maximálně možného idiomatického („volného“) překladu, při stálém zachování sdělení („věrnost“ překladu), včetně terminologické správnosti. Při srovnání s předpokládaným výchozím textem (např. v angličtině) se jak větná struktura, tak užité formulace jeví strukturálně výrazně odlišně, a to nad rámec uplatnění konstitutivních posunů, vyplývajících z rozdílnosti jazyků. Výsledkem je (žádoucí) výrazná redukce administrativního stylu (či snad eurožargonu), pocitovaného jako stylistický kaz.

57 K tématu automatizace překladových příruček a stylistických pokynů srov. Svoboda 2013.

58 Myšlenku automatizace pravidel vstupujících do překladového procesu by jistě J. Levý nevyloučil, vždyt pro něj je kód (tedy závazné instrukce, ovlivňující genezi díla), jak jsme již uvedli, „dokonale formalizovatelný soubor pravidel“ (Levý 1971: 99, zvýraznění přidáno, viz zde též pozn. pod čarou č. 5 výše). 
minovalo ta paradigmata, jež obsahují instrukce, kde výběr je předem dán (jakési „konstitutivní instrukce). ${ }^{59}$ Složitější rozhodnutí by samozřejmě byla ponechána na překladateli.

V souvislosti s problematikou výběru jazykových prostředků uvádí Levý, že „struktura paradigmatu - tj. jeho rozsah a uspořádání - je závislá na materiálu, z něhož je ,sestavena“" ${ }^{60}$ Aplikujeme-li tuto myšlenku opět na odborný, či institucionální překlad, znamená to, že různá paradigmata (např. preferovaná slovní zásoba pro určitou oborovou oblast) jsou v jednom jazyce segmentována jemněji (s vyšším/jemnějším „rozlišením“), v jiném hruběji (s nižším rozlišením). Například pro oblast terminologie EU ${ }^{61} \mathrm{v}$ závazné terminologické databázi IATE (jež je také nepochybně významnou specifikací, překladatelským zdrojem či příručkou v širším slova smyslu) lze pozorovat známý jev, kdy systém terminologie v jazycích států, které k EU přistoupily později, je zpravidla méně propracovaný ve srovnání s jazyky zemí, které jsou členy EU delší dobu (protože se samozřejmě této činnosti mohly věnovat déle).

Jako př́iklad aplikace distinkce č. 9 (Instrukce pro výběr) uved’me u prvního kritéria (objektivní instrukce, zahrnující kontext) problematiku intertextovosti (při překladu právních, a zejména legislativních textů se musí zohlednit kontext předchozích právních předpisů $\mathrm{v}$ dané věci), přičemž požadavek na její dodržování je zakotven např. v příručce Vyhledávání předpisů EU. ${ }^{62}$ U subjektivních instrukcí je na místě myšlenkové propojení s problematikou dnes používaného počítačem podporovaného překladu, jehož hlavní součástí je technologie překladové paměti (translation memory). Ta do určité míry účinně supluje Levým u tohoto kritéria postulovanou „lingvistickou pamět překladatele“, a to at’ už se bude jednat o idiolekt překladatele, nebo závazně předepsané formulace. A jsou to, do třetice, intersubjektivní instrukce pro výběr, jež podle Levého zahrnují estetickou normu, podle naší aplikace se pak jednoznačně jedná např. o psaná pravidla (překladové př́ručky a stylistické pokyny) nebo pravidla nepsaná (v průběhu času intersubjektivně utvářený „house style“ určité instituce).

Jak je patrné, formalizovaný model vytváří strukturu, podle níž lze překladové příručky a stylistické pokyny úspěšně kategorizovat, tedy přiřazovat je k jednotlivým distinkcím (distinkce č. 1-10).

59 Jako př́ílad uved’me rozhodování na úrovni pravopisu, kdy překladatel volí mezi psaním velkého písmene U ve slově Unie. Jak známo, ve výrazu Evropská unie je př́pustné pouze psaní malého písmena (u), avšak pravopis s velkým písmenem (Unie) lze použít, stojí-li slovo samostatně. Správnou pravopisnou variantu by mělo být možné zajistit automatizací - algoritmus automaticky převede všechna eventuální znění Evropská Unie na správnou podobu Evropská unie. Rovněž s pokročilým rozpoznáváním kontextu by postupem času mohl takový algoritmus správně určit, kdy je náležité psát Unie.

${ }^{60}$ Levý 1971: 79.

61 Avšak i uvnitř samotného souboru překladových př́ruček a stylistických pokynů je patrná různá míra rozvrstvenosti, detailu zpracování, obsažnosti atd., srov. Svoboda 2013 a Svoboda 2017.

62 Srov. následující pokyn: „Každý nový předpis musí terminologicky i formulačně přesně odpovídat již přeloženým textům. [...] Pokud se v překládaném textu odkazuje např. na termín definovaný v čl. 2 bodě 5 směrnice XY, je potřeba se do citovaného bodu podívat a český ekvivalent přesně př̀evzít.", https://ec.europa.eu/info/sites/info/files/czech_resources_search_eu_legislation_summary_cs.pdf (cit. 4. 6. 2019). 


\section{Omezení výzkumu a výhled do budoucna}

Přítomné pojednání se zabývá rozhodovacím procesem v překladu pod zorným úhlem J. Levého. Nepochybně existuje řada dalších (pozdějších) prŕistupů psycholingvistických či translatologických, včetně výzkumu kognitivních procesů. Pro účely propojení tématu s oblastí institucionálního překladu se však zde zvolený prŕístup kvưli možnosti systematizace a aplikování na překladové příručky a stylistické pokyny jeví jako velmi patřičný. Jistě však bude v budoucnu možné a vhodné problematiku rozhodovacího procesu v oblasti institucionálního překladu zkoumat právě a též se zapojením i dalších přístupů.

Z kapacitních důvodů jsme se soustředili na díla Levý 1971 a Levý 1967. Další přesahy tohoto tématu v dalších Levého pracích sice zmiňujeme též, na rozdíl od děl Levý 1971 a Levý 1967 jsme však u nich nepřistoupili k vyčerpávající rešerši. V úvahu tak přichází rozšíření zde prezentované taxonomie o distinkce, jež lze odvodit $\mathrm{z}$ dalších Levého textů - např. volba př̀kladové strategie či metody, srov. Levý 1963/1998). Vzniklý model by pak mohl být dále využit pro účely translatologické analýzy, a to pro relativně široké spektrum žánrů či textových typů.

Rovněž jsme Levého model rozhodovacího procesu aplikovali na zvolenou oblast institucionálního překladu pouze náznakově, s uvedením relativně malého množství překladových příruček či stylistických pravidel. Do budoucna se nabízí možnost využít potenciál uvedeného modelu pro systematizaci většího počtu překladových příruček či specifikací.

Grafické znázornění modelu (srov. obr. č. 2) je jistě poněkud zjednodušující, kdy např. některé navržené distinkce nejsou vždy relevantní pro obě roviny překladatelského procesu (recepci a genezi díla/textu) zároveň. Pro názornost však, domníváme se, mưže být takovéto vyobrazení užitečné.

Zároveň si uvědomujeme, že i podobný rozhodovací proces, jaký probíhá na úrovni překladatele $\mathrm{v}$ institucionálním prostředí, probíhá $\mathrm{v}$ širším překladovém procesu rovněž při hodnocení či opravě přkekladového produktu - tedy během fáze revize či korektury, kdy jsou překladatelská řešení posuzována s přihlédnutím k predepsaným př́ručkám. Zde se již jedná o rozhodovací proces v rámci kritiky překladu (hodnocení kvality apod.), který rovněž čeká na své bližší prozkoumání.

Jako velmi nosný pojem pro další translatologické zkoumání pokynů determinujících překladový/překladatelský proces považuji pojem normén. Pomocí tohoto pojmu by mělo být možné jednotlivá konkrétní pravidla více odlišit, blíže definovat, popř́ípadě dále systematizovat.

\section{Závěr}

V tomto příspěvku shrnujeme Levého pojetí rozhodovacího procesu v překladu a systematizujeme je do podoby modelu. Následně takto získaný model aplikujeme na oblast institucionálního překladu, zejména pak na problematiku překladových prríruček a stylistických pokynů. Ukázalo se, že aplikace na neliterární překlad je možná, což potvrdilo zjištění jiných prací zabývajících se Levého myšlenkami, že systém, který Levý ve své (proto)teorii př̀ekladu předkládá, je systém vskutku otevřený. 
V článku jsme dále srovnali dvě poněkud odlišné verze Levého pojetí překladového/ překladatelského procesu (Levý 1967 a Levý 1971). Z tohoto srovnání vyplývá, že v precizované verzi svého konceptu (1971) cíleně akcentoval (jazykový, a zejména mimojazykový) kontext jako hlavní objektivní kritérium určující překladatelova rozhodnutí. Dále jsme konstatovali, že v Levého novějším pojednání o rozhodovacím procesu je důležitý prvek intersubjektivity.

Pokyny existující v oblasti institucionálního překladu pak lze vhodně podle modelu rozhodovacího procesu kategorizovat, vždyt právě takový proces mají daná pravidla regulovat. Aplikovatelnost utvořeného modelu a jeho relevance se zdají být značné, a to zvláště pro účely kvalitativní analýzy překladových příruček a stylistických pokynů, jež dosud pro žádnou instituci nebyla uskutečněna. ${ }^{63}$ Jedním $z$ důvodů může být právě to, že dosud pro takovou analýzu nebyl předložen vhodný model.

Při aplikaci jsme výběrově prokázali, že $\mathrm{k}$ různým distinkcím $\mathrm{v}$ rámci modelu rozhodovacího procesu (distinkce č. 1 až 10) lze přiřadit různé překladové př́ručky a stylistické pokyny a takto příručky kategorizovat (byt mnohdy určitá př́ručka samozřejmě pokrývá více fází či distinkcí překladového/překladatelského procesu). $Z$ aplikace vyplynuly i některé překvapivé postř̌ehy, např́ílad možnost podle vytvořeného modelu systematizovat nejen běžné překladové př́ručck, nýbrž i příručky obsahující pravidla pro používání ostatních příruček (bazální vs. metaúroveň, srov. distinkce č. 2), či současná možnost do úvah zapojit technologii překladové paměti jako určitou nepř́ímou extenzi (či rozšiř̌ní ve smyslu tzv. rozšířené reality) překladatelovy individuální paměti (srov. výše aplikaci distinkce č. 9).

Opět se tak ukazuje šíře dosahu Levého myšlenek i nadčasovost jeho teoretického př́istupu - v době, kdy svá pojednání psal (60. léta 20. století), nebyl institucionální překlad zdaleka tak rozvinutý a pravděpodobně mnohdy ani tak pravidly usměrněný (a už vủbec ne teoreticky rozpracovaný) jako dnes. Přesto Levého odvážné a průkopnické myšlenky a postřehy týkající se rozhodovacího procesu v literárním překladu, a aplikovaně i v překladu neliterárním, odborném, institucionálním, zůstávají stále mohutnou inspirací pro další výzkum.

\section{BIBLIOGRAFIE}

Alexieva, Bistra (1998) 'Consecutive Interpreting as a Decision Process', in Ann Beylard-Ozeroff - Jana Králová-Kullová - Barbara Moser-Mercer (eds.) Translators' strategies and creativity: selected papers from the 9th International Conference on Translation and Interpreting, Prague, September, 1995: in honor of Jiř́ Levý and Anton Popovič, Amsterdam: John Benjamins.

Atari, Omar F. - Al-Sharafi, Abdul Gabbar (2012) 'Split Loyalties. The Translator between Translating Institutions' Norms and Translation Theories', The Interpreter and Translator Trainer 6(2): 195-217.

Bednárová-Gibová, Klaudia (2016) 'Towards an Understanding of EU Translation', Prešovská univerzita v Prešove: http://www.pulib.sk/web/kniznica/elpub/dokument/Bednarova3 (access: 23. 5. 2019).

Biel, Łucja (2014) 'Lost in the Eurofog: the textual fit of translated law', Frankfurt am Main: Peter Lang.

Broeck, Raymond van Den (2018) 'Translational Interpretation: A Complex Strategic Game', in Ann Beylard-Ozeroff - Jana Králová-Kullová - Barbara Moser-Mercer (eds.) Translators'strategies and

63 Srov. závěry výzkumu in Svoboda 2017. 
creativity: selected papers from the 9th International Conference on Translation and Interpreting, Prague, September, 1995: in honor of Jiř́ Levý and Anton Popovič, Amsterdam: John Benjamins.

Čermák, Petr (2016) 'La traducción como proceso de decisiones: su reflejo en los corpus paralelos', Mutatis Mutandis 9(2): 224-246.

Drugan, Joanna (2004) 'Multilingual document management and workflow in the European institutions', in Proceedings of ASLIB Translation and the Computer 26.

Englund Dimitrova, Birgitta (2005) 'Expertise and Explicitation in the Translation Process', Amsterdam/ Philadelphia: John Benjamins.

Evropská komise (2017) 'Translation tools and workflow', Generální ředitelství pro překlady: https:// publications.europa.eu/en/publication-detail/-/publication/00e51a8e-9c50-11e6-868c-01aa75 ed71a1/language-en (access: 23. 5. 2019).

Felici, Annarita (2010) 'Translating EU law: legal issues and multiple dynamics', Perspectives 18(2): 95-108.

Gerzymisch-Arbogast, Heidrun (1996) Termini im Kontext, Forum für Fachsprachen-Forschung 31, Tübingen: Narr.

Halverson, Sandra L. (2008) 'Translations as institutional facts: An ontology for "assumed translation"', in Anthony Pym - Miriam Shlesinger - Daniel Simeoni (eds.) Beyond Descriptive Translation Studies. In Homage to Gideon Toury, Amsterdam: John Benjamins, 343-362.

Hanzl, Jan (2006) Překlad právních předpisů Evropských společenství v České republice a dalších nových členských státech EU (Project Management a sociologie jednotlivých subjektů vstupujících do procesu překladu), Praha: Univerzita Karlova: https://is.cuni.cz/webapps/zzp/detail/26779 (access: 4. 6. 2019).

Jettmarová, Zuzana (2009) Kontexty (v) překladovosti, Praha: Univerzita Karlova, Filozofická fakulta.

Jettmarová, Zuzana (2016) Mozaiky prekladu, Praha: Karolinum.

Kang, Ji-Hae (2009) 'Institutional Translation', in Mona Baker - Gabriela Saldanha (eds.) Routledge Encyclopaedia of Translation Studies, London a New York: Routledge, 141-144.

Kang, Ji-Hae (2014) 'Institutions translated: discourse, identity and power in institutional mediation', Perspectives 22(4): 469-478.

Koskinen, Kaisa (2000) 'Institutional Illusions', The Translator 6(1): 49-65.

Koskinen, Kaisa (2008) Translating Institutions. An Ethnographic Study of EU Translation, Manchester: St. Jerome.

Kußmaul, Paul (1986/1994) 'Übersetzen als Entscheidungsprozeß. Die Rolle der Fehleranalyse in der Übersetzungsdidaktik', in Mary Snell-Hornby (ed.) Übersetzungswissenschaft - eine Neuorientierung, 2. vyd. 1994, UTB 1415, Tübingen/Basel: Francke, 206-229.

Levý, Jiř́ (1967) 'Translation as a decision process', in To Honor Roman Jakobson: Essays on the occasion of his seventieth birthday, vol. 2, The Hague: Mouton, 1171-1182.

Levý, Jiří (1971) Bude literární věda exaktní vědou?, Praha: Čs. spisovatel.

Levý, Jiř́i (1963/1998) Umění překladu, Praha: Ivo Železný.

Ljudskanov, Alexander (1980) 'Prevezhdat chovekut i mashinata (Man and computer translation)' in Elena Paskaleva (ed.) Collected Works, Sofia: Narodna Kultura.

Mathesius, Vilém (1982) 'Užitečnost konvence’ in Týž, Jazyk, kultura a slovesnost, Praha: Odeon.

Mossop, Brian (1990) 'Translating Institutions and "Idiomatic" Translation', Meta 35(2): 342-355.

Obdržálková, Vanda (2016) 'Translation as a decision-making process: an application of the model proposed by Jiř́ Levý to translation into a non-mother tongue', Mutatis Mutandis 9(2): 306-327.

Obrová, Pavlína - Pelka, Jiří (2001) 'Překládání práva ES do češtiny / Translation of EC Law into Czech', Terminologie et Traduction 2001(2), Lucemburk: Evropská komise.

Reiß, Katharina (1976/1993) Texttyp und Übersetzungsmethode, 3. vyd. 1993, Heidelberg: Groos.

Reiß, Katharina (1981/2000) 'Type, Kind and Individuality of Text. Decision Making in Translation', in: Lawrence Venuti (ed.) The Translation Studies Reader, London/New York: Routledge, 160-171.

Schäffner, Christina - Tcaciuc, Luciana Sabina - Tesseur, Wine (2014) 'Translation practices in political institutions: a comparison of national, supranational, and non-governmental organisations', Perspectives 22(4): 493-510.

Schubert, Klaus (2007) Wissen, Sprache, Medium, Arbeit. Ein integratives Modell der ein- und mehrsprachigen Fachkommunikation, Forum für Fachsprachen-Forschung 76, Tübingen: Narr. 
Schubert, Klaus (2009) 'Kommuniationsoptimierung. Vorüberlegungen zu einem fachkommunikativen Forschungsfeld', Trans-kom 2(1): 109-150.

Svoboda, Tomáš (2008) 'Ubi sunt homines? Poznámky k řízení kvality překladů u Generálního ředitelství pro překlad Evropské komise’, in Od textu k překladu, Praha: Jednota tlumočníků a překladatelů.

Svoboda, Tomáš (2013) 'Translation Manuals and Drafting Style Guides at the European Commission', Le Bulletin du CRATIL Centre de recherche de l'ISIT, 5(10): https://www.academia.edu/11956001 /Translation_Manuals_and_Drafting_Style_Guides_at_the_European_Commission (access: 23. 5. 2019).

Svoboda, Tomáś (2017) 'Translation manuals and style guides as quality assurance indicators: The case of the European Commission's Directorate-General for Translation', in Tomáš Svoboda - Łucja Biel - Krzysztof Łoboda (eds.) Quality aspects in institutional translation, Berlín: Language Science Press, http://langsci-press.org/catalog/book/181 (access: 23. 5. 2019).

Svoboda, Tomáš (2018) 'Institutional translation in national contexts. Quality assurance in governmental institutions across Europe’, in Éric Poirier - Daniel Gallego Hernández (eds.) Business and Institutional Translation: New insights and reflections, Québec: Cambridge Scholars Publishing.

Svoboda, Tomáš (2019) Překlady pro EU, Praha: Nakladatelství Milada Karez.

Toury, Gideon (1980) In Search of a Theory of Translation, Tel Aviv: Porter Institute for Poetics and Semiotics, Tel Aviv University.

Wilss, Wolfram (1988) ‘Übersetzen als Entscheidungsprozeß’, in: Reiner Arntz (ed.) Textlinguistik und Fachsprache, Studien zu Sprache und Technik 1, Hildesheim/Zürich/New York: Olms, 7-20.

Wilss, Wolfram (1998) 'Decision Making in Translation', in: Mona Baker - Kirsten Malmkjær (ed.) Routledge Encyclopedia of Translation Studies, vyd. 2001, London/New York: Routledge, 57-60.

\section{RESÜMEE}

Dieser Aufsatz verbindet drei Bereiche: das Übersetzen als Entscheidungsprozess, den wissenschaftlichen Fachbereich der sog. institutionellen Übersetzung sowie Übersetzungshandbücher und stilistische Leitfäden.

Die menschliche Übersetzung ist grundsätzlich ein Entscheidungsprozess. Der eigentliche Prozess unterliegt vielen Normen, Spezifikationen und anderen einschränkenden Merkmalen. Dies gilt sowohl für die literarische als auch für die Fachübersetzung. Der vorliegende Beitrag stellt die institutionelle Übersetzung als Entscheidungsprozess dar und zwar unter besonderer Berücksichtigung von Übersetzungshandbüchern und stilistischen Leitfäden.

Der Aufsatz ist in zwei Hauptteile gegliedert: Im ersten Teil wird Jiří Levýs Konzept des Übersetzens als Entscheidungsprozess zu einem Modell formalisiert. Das Modell beinhaltet eine Taxonomie von zehn Unterschieden: 1) Auswahl des zu übersetzenden Textes, 2) Primär-vs. Metaebene, 3) Unterordnung von Paradigmen und Instruktionen, 4) Akzeptanz vs. Nicht-Akzeptanz der Instruktionen, 5) quantitativer vs. qualitativer Aspekt des Entscheidungsprozesses, 6) Anzahl der von einem Übersetzer getroffenen Entscheidungen im Vergleich zu denen des ursprünglichen Autors, 7) notwendige vs. unnötige Überschussentscheidungen, 8) motivierte vs. nicht motivierte Entscheidungen, 9) Auswahlinstruktionen, 10) bewusste vs. unbewusste Entscheidungen. Das Modell wird dann als ein übersichtliches Ablaufdiagramm dargestellt.

Der Text vergleicht auch relevante Passagen, die in der früheren englischen Fassung von Levy's Translation as Decision Process (1967) und der tschechischen Version von 1971 im Hinblick auf den Entscheidungsprozess bei der Übersetzung enthalten sind. Der Vergleich zeigt eine Verschiebung in Levýs Verständnis vom Übersetzungsprozess im Laufe der Zeit.

Im zweiten Teil wird die oben genannte Taxonomie auf Fachübersetzungen angewendet, insbesondere auf den relativ stark regulierten Kontext der institutionellen Übersetzungen. Da die institutionelle Übersetzung oft durch (schriftliche und ungeschriebene) Regeln geregelt wird, die die Entscheidungen der Übersetzer beeinflussen, spielen Übersetzungshandbücher und stilistische Leitfäden eine Schlüsselrolle im Entscheidungsprozess eines Übersetzers. Die Verknüpfung des erarbeiteten Modells mit sol- 
chen Handbüchern und/oder stilistischen Leitfäden hat sich als geeignet erwiesen, eine Taxonomie für letztere zu erstellen, die seit Beginn der wissenschaftlichen Erforschung dieser Ressourcen stets fehlte. Das Modell ermöglicht es, Unterschiede zwischen verschiedenen Arten von institutionellem Diskurs zu überbrücken (hier werden beispielsweise supranationale, korporative sowie non-profit Organisationen untersucht). Der vorliegende Aufsatz schlägt daher ein allgemeines Systemisierungsraster für Übersetzungshandbücher und stilistische Leitfäden vor, indem die einzelnen Ressourcen den Distinktionen (Nr. 1 bis 10) des Modells zugeordnet werden. Darüber hinaus verweist der Beitrag auch auf das Potenzial der Spieltheorie zur Erforschung institutioneller Übersetzung.

PhDr. Bc. Tomáš Svoboda, Ph.D.

Ústav translatologie, Filozofická fakulta, Univerzita Karlova

tomas.svoboda@ff.cuni.cz 